\title{
MINORIAS RELIGIOSAS E LAICIDADE ESTATAL: PROTEÇÃO À LIBERDADE DE CRENÇA E TOLERÂNCIA RELIGIOSA NO BRASIL CONTEMPORÂNEO
}

\author{
${ }^{1}$ Antonio Celso Baeta Minhoto
}

\begin{abstract}
RESUMO
A religião sempre esteve presente nos relacionamentos humanos ao longo da história e, do mesmo modo, nos conflitos e manifestações de intolerância. Neste estudo, buscamos traçar uma visão sobre religião, liberdade religiosa e tolerância, destacando especialmente o relacionamento entre os adeptos de grupos religiosos minoritários, mais especialmente ainda mencionando situação de conflito instalada entre adeptos de cultos afro e fiéis ligados à igrejas evangélicas, de recente expansão na realidade brasileira. Vislumbrar que tipo de desdobramento esses elementos possam vir a ter no futuro é um dos objetivos desse estudo, bem como identificar alguns aspectos de intolerância religiosa no mundo
\end{abstract}

Palavras-chave: Religião, Minorias, Laicidade, Tolerância

\section{MINORIAS RELIGIOSAS Y LAICIDAD ESTATAL: PROTECCION A LA LIBERTAD DE CREENCIA Y TOLERANCIA RELIGIOSA EN BRASIL CONTEMPORANEO}

\section{RESUMEN}

la religion siempre estuvo presente en los relacionamientos humanos al largo de la historia y, aun mas, en los conflictos y manifestaciones de intolerancia. En ese estudio, buscamos dibujar una vision acerca de religion, libertad religiosa y tolerancia, destacando de manera especial el relacionamiento entre los creyentes de grupos minoritários, más especialmente el conflicto instalado entre adeptos de cultos afro y fieles de iglesias evangélicas. Vislumbrar que tipo de consecuencia o perspectiva eso tenga o posa vir a tener en el futuro es un de los objectivos de ese estúdio, bien como identificar aspetos de intolerancia religiosa en el mundo.

Palabras-claves: Religiones, Minorias, Laicidade, Tolerancia

\footnotetext{
1 Doutor em Direitos Fundamentais e Inclusão Social pela Instituição Toledo de Ensino Bauru, São Paulo - ITE, Brasil. Professor do Curso de Mestrado na Universidade de Marília - UNIMAR, Brasil. E-mail: antonio@baetaminhoto.com.br (Brasil)
} 


\section{INTRODUÇÃO}

Tema de constante interesse ao longo da história, mas relativamente pouco pesquisado no Brasil, a religião e os outros institutos que a perpassam, como, por exemplo, tolerância e liberdade, parecem estar recebendo mais atenção e mais interesse, não somente no ambiente acadêmico, mas na sociedade de um modo geral.

Certamente colabora para essa mudança uma outra operada na população brasileira nos últimos tempos: a sensível mudança no panorama das religiões, com um notável incremento do contingente de evangélicos e um não menos notável decréscimo entre os católicos, numa interessante dinâmica "minoria-maioria".

Neste estudo, analisaremos alguns aspectos da liberdade religiosa e ajustaremos nosso foco, numa segunda parte, à situação das religiões afro-brasileiras, especialmente frente ao ascendente contingente de evangélicos, estabelecendo-se entre tais grupos um relacionamento que tem se revelado conflituoso e cujos desdobramentos futuros são ainda incertos.

A tolerância é aspecto final a ser aqui abordado. Estaríamos frente a uma espécie de retorno aos tempos de perseguição religiosa, tal como vimos na Europa nos séculos XV e XVI, que culminaram na reforma protestante? Ainda que o âmbito da comparação ora proposta seja evidentemente menor em suas proporções e características, não podemos deixar de analisar se, ao menos estruturalmente, existe essa identificação.

Essa tolerância, ainda mais, deve ser vista no contexto de um Estado fundamentalmente laico, mas que, tal como o direito, já não pode mais pretender-se neutro, sob pena de por a perder importantes conquistas contemporâneas, como, no caso, a dignidade da pessoa humana como um de seus vetores fundamentais.

\section{RELIGIÃO E RELIGIOSIDADE}

A religião e o sentimento de religiosidade é algo tão inerente à caminhada do homem na Terra que se deve ajustar o foco de qualquer análise a fim de se evitar uma sucessão de clichês. Neste sentido, parece-nos de bom tom não trazer ou tentar trazer aqui definições ou mesmo uma definição para religião, mas algumas ideias conceituais sobre tal tema.

Assim, sem pretender esgotar assunto algum, entende o autor ser interessante mencionar algumas ideias sobre o que seria religião ou sobre o sentimento de religiosidade, de buscar uma conexão com o sagrado, com o divino, algo importante, imagina-se, para situar questionamentos futuros e para podermos aprofundar de modo mais adequado alguns aspectos aqui abordados. 
Schleiermacher, de modo bastante resoluto, afirma ser religião "um sentimento ou uma sensação de absoluta dependência" (2000:23), uma afirmação que não parece ser inverídica, mas que, ao mesmo tempo, não se mostra tão completa quanto seria um certo ideal neste campo. Imaginar o sentimento de religiosidade apenas e tão-somente como uma manifestação de dependência, de carência e até mesmo de subserviência, de fato soa incompleto.

Desse modo e buscando essa completude, encontramos Glasenapp com uma síntese mais ampla, talvez menos formal que a de Schleiermacher, defendendo ser religião " $a$ convicção de que existem poderes transcendentes, pessoais ou impessoais, que atuam no mundo, e se expressa por insight, pensamento, sentimento, intenção e ação" (2002:17).

A religião, de qualquer maneira, e seja qual for o modo ou forma de sua manifestação, sempre busca ao menos dois elementos, quais sejam a transcendência e a conexão (ou reconexão). A transcendência retira o crente de sua condição humana comum, até mesmo inferior e o alça a algo pretensamente superior, elevado, livre das "impurezas" ou das falhas daquele que busca tal transcendência, o crente.

A conexão é conseqüência da transcendência. Uma vez elevado de sua condição humana comum, o rito, o meio, a forma escolhida pelo religioso, ou crente, visa estabelecer sua conexão com esta esfera superior, extra-mundo, com a qual quer manter contato e ligação.

E neste ponto, desta junção dos elementos acima dispostos, que observamos o surgimento de um elemento importantíssimo na vivência religiosa que vem a ser a noção do sagrado. Remontando a própria formação morfológica do termo, Gaarder expõe que "sagrado indica algo que é separado e consagrado; profano denota aquilo que está em frente ou do lado de fora do templo" (2002:19), mas é Rudolf Otto (1985:32) quem, sobre tal idéia, traz a observação mais interessante:

O sagrado é aquilo que é totalmente diferente de tudo o mais e que, portanto, não pode ser descrito em termos comuns (...) É uma força que por um lado engendra um sentimento de grande espanto, quase de temor, mas por outro lado tem um poder de atração ao qual é difícil resistir

Por fim, encerrando este nosso breve tópico, comentamos um último termo que frequentemente é associado à religião que vem a ser a magia. Nem todas as religiões se valem de tal noção para expressar suas próprias concepções sobre o sagrado e a busca de conexão com este aspecto, mas é, de todo modo, um termo presente neste campo temático e deve ser levado em conta.

Mas, como podemos ver abaixo na arguta citação de Gaarder (2002: 25), magia é algo diverso de religião e pode até mesmo se colocar, dependendo do contexto, como algo 
contrário à religião, especialmente se concebida de um modo mais ortodoxo ou tradicional.

Vejamos:

Magia é uma tentativa de controlar os poderes e as forças que operam na natureza. Costuma-se encontrar a magia em contextos religiosos, e é difícil traçar uma linha divisória nítida entra a religião e a magia, entre uma reza um encantamento. A distinção que mais sobressai é o fato de, na religião, o indivíduo se sentir totalmente dependente do poder divino. Ele pode fazer sacrifícios aos deuses ou se voltar para eles em oração; porém, em última análise, deve aceitar a vontade divina

O autor arremata a exposição acima, dizendo:

Quando, por outro lado, o ser humano se vale dos ritos mágicos, ele está tentando coagir as forças e potências a obedecer à sua ordem - que com freqüência consiste em atingir finalidades bem concretas. Desde que os rituais mágicos sejam realizados corretamente, o mago acredita que os resultados desejados decerto ocorrerão, por uma questão de lógica. Se ele falhar, irá culpar um erro em seu ritual, ou o uso de um feitiço mais forte contra si

Sem dúvida a distinção pode se revelar tormentosa, porque ambos os sentimentos, religião e magia, buscam uma conexão transcendental que os une de modo bastante próximo. Agregue-se a isso, ainda, a conexão a um espaço comum, um solo ancestral em que rituais são executados de modo regular e de geração em geração. Além disso, há o pertencimento de um indivíduo a um grupo que reparte, convive e participa das mesmas concepções do sagrado, do divino e do mágico, e teremos, assim, ainda uma terceira situação em que todos esses elementos se entrecruzam.

No sentido acima apontado, Louth (1979:304) nos relata que "os cantos dos Germanos, seus costumes e seus deuses, tanto nos fiordes como às margens do Reno, estão marcados por uma intuição primordial: a grandeza do homem está em realizar o seu destino no seio do seu clã" e Granet (1979:11), mencionando a questão do espaço físico, do solo tido por sagrado por aquela comunidade, afirma que na China antiga:

Nos Lugares-Santos, realizavam-se grandes festas que eram também feiras: ali se comunicava com o solo natal; convidavam-se os antepassados a vir se reencarnar. - a cidade nobre é santa; ela contém um mercado, um altar do Solo, um templo de Ancestrais. A cidade do fundador de uma dinastia senhorial traz o título de Tsong. Emprega-se, também, esta palavra para designar os grupos de pessoas unidas pelo culto de um mesmo ancestral

Relativamente às religiões afro-brasileiras - que aqui reduziremos, apenas para fins de estudo e por questões até de espaço, para Candomblé e Umbanda - os aspectos acima pontuados são de extrema relevância. Candomblé e Umbanda são religiões calçadas na magia e na prática de rituais, sem o que a transcendência e a conexão antes comentadas não se realizam. Não há sentido, portanto, para um adepto de tais religiões em abrir mão de atos e 
procedimentos absoluta e rigorosamente vitais à própria existência de sua fé e de sua crença.

Mas são justamente tais aspectos, repita-se fundamentais a tais religiões, que as colocam em situação de atrito com os evangélicos, como veremos adiante, muito embora tenhamos que adiantar, desde já, que se trata de um atrito de defesa (religiões afro) em face de um ataque (evangélicos).

\section{CONCEITO DE MINORIA ${ }^{1}$}

Minoria é algo hoje presente nos mais variados discursos e nos mais variados campos de estudos. Ideia fundamentalmente ligada à inclusão social, minoria, por outro lado, ou não tem recebido um enfoque científico mais adequado, ou torna-se refém de toda sorte de abordagens, o que não é algo propriamente nocivo, mas que pode gerar uma perda de objetividade em sua análise. Nosso foco será conceituar e não definir, algo mais aberto e menos rigoroso do que uma definição..

A ONU, através de Resolução, ainda no ano de 1954, buscou conceituar o termo minoria e o fez afirmando ser "aqueles grupos não dominantes dentro de uma população, que possuem e desejam preservar tradições ou características étnicas, religiosas ou lingüísticas marcadamente diferentes do resto da população".

\footnotetext{
${ }^{1}$ Muitas das idéias e conceitos expostos neste item foram fruto de intenso debate no programa de doutorado da Instituição Toledo de Ensino, de Bauru, SP, do qual foi o autor integrante como aluno, tendo tomado parte em tal debate Fábio Alexandre Coelho, Cleber Sanfelice Otero e Antonio Borges de Figueiredo, também alunos do programa em foco, além do professor Vidal Serrano Nunes Junior, em cujas aulas se pôde desenvolver o tema aqui referenciado. A mesma exposição de ideias consta em outro artigo do autor, já publicado: $O$ federalismo brasileiro e a questão das competências constitucionais relativas à acessibilidade e inclusão social do portador de deficiência. São Paulo: Revista do Instituto dos Advogados de São Paulo, 2008, p. 21-35.
}

É uma colocação histórica e importante, especialmente porque emanada de instituto supraestatal de inegável relevância e respeitabilidade. Mas, respeitosamente, ousamos avançar a ofertar uma análise que se nos afigura mais completa e consentânea com a configuração atual de nossa sociedade. A nosso sentido, podemos dizer que um grupo minoritário apresenta as seguintes características, com as quais, depois, formularemos nosso próprio conceito:

2.1. Incapacidade de Auto-Proteção. As minorias se mostram incapazes, no mais das vezes ao menos, de se protegerem e de protegerem seus interesses de modo independente ou autônomo.

2.2. Demandantes de Especial Proteção Estatal. Justamente em decorrência de uma reconhecida e notória incapacidade de articulação e autonomia na busca de defesa de seus interesses, os integrantes das minorias demandam especial atenção do Estado, manifestada 
através de mecanismos, de instrumentos, de estruturas cujo escopo final seja oferecer aos integrantes destas minorias, tal como aqui exposto, as mesmas oportunidades oferecidas aos não integrantes destes grupos.

2.3. Vulnerabilidade Social. Por diversas e variadas razões, ou por vezes em decorrência de poucos motivos, o integrante de uma minoria encontra-se em situação de vulnerabilidade social. O que seria, por sua vez, vulnerabilidade social ? Em arguta observação, Muniz Sodré (2005:11) nos informa ser a vulnerabilidade social caracterizada pelo fato do grupo minoritário "não ser institucionalizado pelas regras do ordenamento jurídico-social vigente", e que, por isso e segundo o mesmo autor, "pode ser considerado 'vulnerável', diante da legitimidade institucional e diante das políticas públicas. Donde sua luta por uma voz, isto é, pelo reconhecimento societário de seu discurso.

2.4. Distanciamento do Padrão Hegemônico. Esta outra característica das minorias tem a peculiaridade de gerar efeitos deletérios aos integrantes das minorias ainda que estes nenhum tipo de ação tomem com relação a si mesmos frente a este padrão. É uma ação involuntária com relação a tais indivíduos e atuante de modo "automático" por parte da sociedade majoritária, ou seja, a sociedade como um todo, excluídas as minorias.

2.5. Opressão Social. Cujos graus serão variáveis e diferenciados em face de cada grupo minoritário, bem como em face de diversas variáveis, muitas delas altamente subjetivas e prenhes de aspectos mutáveis, o que torna sua própria dinâmica movediça e frequentemente imprevisível.

Destarte, minoria é um segmento social, cultural, religioso ou econômico vulnerável, incapaz de gerir e articular sua própria proteção e a proteção de seus interesses, objeto de préconceituações e pré-qualificações de cunho moral em decorrência de seu distanciamento do padrão social e cultural hegemônico, vitimados de algum modo e em graus variados de opressão social e, por tudo isso, demandantes de especial proteção por parte do Estado.

\section{TOLERÂNCIA RELIGIOSA}

Convém fazer aqui, neste ponto, breve digressão histórica, a fim de melhor situar o tema deste tópico, eis que não se observa um surgimento concomitante de liberdade religiosa e proteção às minorias religiosas, como se poderia supor, mesmo no âmbito do constitucionalismo e da proteção estatal ofertada à sociedade no bojo do ideário típico das revoluções do final do século XVIII.

Desde o início da Idade Média pretendia a Igreja a junção do poder transcendental ou divino com o poder secular, justificando tal entendimento justamente na simples existência do primeiro e de sua alegada preeminência sobre aquele outro. 
Nesse sentido, sempre quis a Igreja o poder terreno e sempre lutou para tê-lo e mantê-lo chegando a, tempos depois, quando pressionada sobre o exercício, por vezes arbitrário, deste mesmo poder terreno que efetivamente exercia, a lançar mão de preceitos religiosos no âmbito da esfera política, tais como as bem conhecidas excomunhões que alguns governantes divergentes experimentaram.

As passagens e acontecimentos envolvendo a Igreja como entidade que chamou para si de modo exclusivo a titularidade do poder terreno ou secular, especialmente na baixa Idade Média, são notórias. Os Papas, àquele tempo, defendiam tal postura de modo expresso (GIERKE, 1995:78):

Como representante de Cristo, la cabeza terrenal de la Iglesia es el titular de lo que en su origen es un principado unitario sobre la comunidad de los mortales, él es su sacerdote e su rey, su monarca espiritual y temporal, su supremo legislador y juez en todos los âmbitos (Gregório VII, lib. I, ep. 1075, sendo que a mesma idéia foi defendida também pelo Papa Inocêncio III, c. 34 , X 1, c. 6, X 1, 3333; c. 13 , X 2, 1).

É de conhecimento comum, contudo, os embates havidos entre papas e reis quanto à titularidade do poder politico. O conflito é bastante lógico se temos em mente que ambos se imaginam oriundos de uma linhagem divina (reis) ou representantes de Deus na Terra (papas). O evento mais destacado neste campo certamente foi a excomunhão do Rei Henrique IV pelo Papa Gregório VII.

Alberto Ribeiro Barros em sua tese de doutorado, nos lembra que a excomunhão em destaque forçou a celebração da "Concordata de Worms", em 1122, sendo ali estabelecido que os bispos seriam escolhidos pelo clero e o imperador teria o direito de decidir as eleições que fossem contestadas (BARROS, 1999: 150)

Bem por isso, Jonatas Eduardo Mendes Machado nos lembra que a proteção estatal à liberdade religiosa surgiu numa dinâmica oscilante e de disputa entre o poder eclesiástico e o poder político terreno, e pouco se assemelhava com a noção de proteção a este instituto tal com concebido no seio do constitucionalismo, tempos depois, o que não afastou os conflitos de outrora, mas acomodou-os na forma de pactos, tratados e concordatas especialmente entre os Soberanos ou governantes e o Papa (1993: 7).

Esses acordos de boa convivência, contudo, jamais conceberam a inclusão protetiva da tutela estatal em prol de qualquer grupo religioso minoritário. A liberdade religiosa, objetivamente, focava-se na fé católica e na chamada fé cristã reformada, advinda dos movimentos religiosos surgidos no próprio seio da Igreja Católica, especialmente a partir do século XVI com Lutero e Calvino.

Àquela época, a proteção efetiva do Estado voltava-se a tais grupos e tão-somente a 
eles. Mais do que isso, essa proteção inicialmente até se fundou em razões subjetivas ligadas à concepções espiritualistas de harmonia entre crentes de uma mesma árvore religiosa - a exemplo do filósofo Erasmo - mas, em pouco tempo essa boa convivência baseou-se, como nos ensina Henry Kamen, em razões eminentemente práticas e ligadas, elementarmente, ao comércio e à economia (1991:216).

Kamen ainda prossegue e, comentando sobre Erasmo, afirma que para ele "como como para otros humanistas contemporâneos, la tolerância no era un ideal; se trataba únicamente de un médio para asegurar esa armonia religiosa que todos los cristianos ansiabán" (1991:217).

O mesmo autor ainda prossegue defendendo razões comerciais para haver tolerância religiosa, e cita comentário de Sir William Petty: “(...) para el progreso del comercio, si es que este es un motivo suficiente, debemos ser tolerantes en cuestiones de opinión” (1991:217).

Por fim, é o próprio Kamen quem afirma que os viajantes protestantes "creían que la pobreza de Espana e Itália era consecuencia directa de su catolicismo intolerante, y que la creciente prosperidad de Inglaterra provenia de su actitud liberal hacia los disidentes, en especial desde 1689. La revocación del edicto de Nantes vino a reforzar esta opinión” (1991:218).

Partindo para as especificidades que circundam o objeto de nosso estudo, observamos, com Contreras Mazario (2004:147), haver uma diferenciação bastante importante no estudo presente e esta se volta para o fato de que algumas minorias buscam sua completa aceitação e inclusão na sociedade de um modo geral enquanto outras perseguem a preservação de seus valores, não hegemônicos, num meio que lhes é naturalmente hostil ou pelo menos não receptivo.

Exemplificativamente, podemos mencionar o exemplo dos negros e da cultura de origem africana. Desinteressa a este tipo de segmento social, deste modo, uma postura puramente preservacionista, eis que tal medida poderia gerar um isolamento de suas manifestações, distanciando-a, assim, de uma virtual (e desejada) junção com a cultura ou com os valores culturais vigentes.

Nada obstante, os cultos africanos, assim como os diversos segmentos religiosos cristãos, para destacarmos um exemplo marcante em nossa sociedade, não são uma manifestação única. Parece-nos suficiente para sustentar tal afirmação a miríade de religiões cristãs com práticas sacras bem distintas entre si. Figure-se o caso do protestantismo, havendo ali sentidas diferenças entre batistas, menonistas, calvinistas, luteranos, puritanos, metodistas e outras linhas menos conhecidas como quakers e amish, conquanto sejam todos cristãos.

Do mesmo modo, e no campo das religiões africanas ou africanas com influência ou 
concepção brasileira, também não se tem um ideário único e nem procedimentos unificados. A Umbanda, que é resultante de um influxo de religiões africanas e brasileiras, tendo recebido também influências do espiritismo kardecista de origem europeia, é um bom exemplo dessa ausência de unidade em suas próprias práticas.

Como nos relata Reginaldo Prandi (2003:15-33), "as religiões afro-brasileiras mais antigas foram formadas no século XIX, quando o catolicismo era a única religião tolerada no País e a fonte básica de legitimidade social", ponderando o mesmo autor que "para se viver no Brasil, mesmo sendo escravo, e principalmente depois, sendo negro livre, era indispensável antes de mais nada ser católico” (2003:15-33).

E mesmo Prandi conclui: "por isso, os negros que recriaram no Brasil as religiões africanas dos orixás, voduns e inquices se diziam católicos e se comportavam como tais. Além dos rituais de seus ancestrais, frequentavam também os ritos católicos. Continuaram sendo e se dizendo católicos, mesmo com o advento da República, quando o catolicismo perdeu a condição de religião oficial" (2003:15-33).

Especificamente no tocante à Umbanda e Candomblé, um outro fator marcante é justamente a falta de interesse em se unificar procedimentos, ideias e ações relacionadas ao culto. Prandi nos lembra que é concepção comum entre os fiéis a máxima "no Candomblé nada pode e tudo pode" e que, por isso, "cada comunidade é livre para experimentar inovações ou retornar à formas anteriores, incorporando práticas que para outros da mesma religião podem não fazer o menor sentido" (2003:15-33).

E essa visão de preservação das particularidades nem é só do Brasil. Neste sentido e citando manifestação da Comissão dos Direitos Humanos da ONU, Contreras Mazario pontua (2004:148):

La protección de las minorias consiste em la protección de los grupos que no son predominantes en un país y que, si bien desean en general ser tratados en pie de igualdad con la mayoria, desean en cierta manera recibir um trato diferente para preservar las características fundamentales que los distinguem de la mayoría de la población

De todo modo, e retornando ao veio principal de nosso estudo, veremos, no tópico seguinte, a questão específica dos evangélicos e de seu relacionamento, via de regra, tormentoso com as religiões afro-brasileiras, especialmente Candomblé e Umbanda.

\section{RELIGIÕES NO BRASIL: OS EVANGÉLICOS, AS RELIGIÕES AFRO-BRASILEIRAS E A [IN]TOLERÂNCIA RELIGIOSA}

Há, no Brasil atual, uma realidade peculiar com relação às minorias religiosas, de 
grande importância nos últimos vinte ou trinta anos, que vem a ser o movimento evangélico, composto de variadas instituições, cuja estruturação varia de pequenas organizações até outras de grande porte, como é o caso, exemplificativamente, da Igreja Universal do Reino de Deus (IURD), dirigida pelo Bispo Edir Macedo; Igreja Mundial do Poder de Deus, coordenada pelo Bispo Valdemiro Santiago; Igreja Internacional da Graça de Deus, tendo à frente o pastor Romildo Ribeiro Soares (R. R. Soares), dentre outras.

Tomando a IURD como referência - sendo que as outras duas igrejas acima mencionadas possuem aspectos bem semelhantes - vemos que ela adquiriu, já há vários anos, um canal de televisão (Record), bem como jornais impressos, emissoras de rádio, participações em outras empresas, além de ter aberto vários templos ao longo do globo.

Possui, desse modo, uma estrutura empresarial com faturamento anual estimado na casa dos 2 bilhões de reais. Frente a uma maioria católica, os evangélicos - e dentre estes os fiéis e integrantes da IURD - são, ou seriam, uma minoria religiosa. No entanto, ainda em 2007, um evento jogou novas luzes sobre esta relação, maioria versus minorias e, nesse entremeio, em face também do Estado.

Em dezembro de 2007, o jornal Folha de São Paulo, o jornal de maior circulação no território brasileiro, publicou uma reportagem sobre a Igreja Universal, sob o título "Igreja Universal completa 30 anos com império empresarial'. O texto questionava a ligação entre atividade empresarial e religiosa da IURD, algo que gerou uma reação da entidade religiosa em foco o que, só por si, seria perfeitamente aceitável num ambiente democrático como o da sociedade brasileira contemporânea, até porque, praticamente no mesmo dia, a Associação Brasileira de Imprensa também divulgou nota de apoio à jornalista.

A questão a ser analisada foi a estratégia adotada pela IURD na seqüência dos fatos. Ao invés de acionar judicialmente o jornal Folha de São Paulo, a IURD teria estimulado seus fiéis e integrantes a entrarem com ações na Justiça de modo isolado, ao mesmo tempo em que incluíam a jornalista autora da matéria, Elvira Lobato, na ação judicial e não apenas o Jornal. O resultado foi um volume grande ações por todo o país, inviabilizando ou dificultando a defesa do Jornal e da jornalista.

Destarte, o caso da IURD acima comentado de modo breve exibiu a articulação de seus fiéis em prol de seus interesses, além de ter se valido a instituição religiosa em foco de toda a sua estrutura de comunicação para cooptar apoios e veicular ideias contrárias à reportagem. Se isso é aceitável ou não, como forma de atuação num ambiente democrático, é uma questão cuja análise não cabe neste estudo, mas mostra - e este é o foco de nossa atenção - peculiaridades da dinâmica maioria-minorias no campo religioso que devem ser levadas em conta.

E justamente neste contexto de articulação é que se insere o relacionamento entre 
evangélicos e as religiões afro-brasileiras. Dois aspectos já trabalham, de plano, desfavoravelmente ao segundo grupo:

a) os evangélicos são um grupo em franca ascensão. Com dados do IBGE, observamos que os evangélicos eram 6,6\% em 1980 e nos anos 2000 representavam 15,4\% da população. Os adeptos das religiões afro, por outro lado, experimentaram percurso inverso. Eram 0,6\% em 1980 e recuaram para 0,3\% da população nos anos 2000.

Para o Censo de 2010, os números acima só se confirmaram em seu aspecto de crescimento: protestantes (com forte ingresso dos evangélicos), foram para 22,2\%; católicos recuaram para 64,6\% e religiões afro-brasileiras sequer foram tratadas como grupo autônomo, estando dispersas entre espiritismo $(2,1 \%)$ e outras religiões $(3,2 \%)$. Vejamos o quadro:

\begin{tabular}{|l|l|l|l|l|}
\hline Religião & 1980 & 1991 & 2000 & 2010 \\
\hline Católicos & 89,2 & 83,3 & 73,7 & 64,6 \\
\hline Evangélicos & 6,6 & 9,0 & 14,4 & 22,2 \\
\hline Espíritas & 0,7 & 1,1 & 1,4 & 2,1 \\
\hline afro-brasileiros & 0,6 & 0,4 & 0,3 & ---- \\
\hline outras religiões & 1,3 & 1,4 & 1,8 & 3,2 \\
\hline sem religião & 1,6 & 4,8 & 7,3 & 9,2 \\
\hline Total & $100 \%$ & $100 \%$ & $100 \%$ & $100 \%$ \\
\hline
\end{tabular}

Fonte: IBGE, Censos Demográficos

b) os evangélicos, sem embargo da extensa variedade de denominações, comungam de valores muito aproximados, assim como estruturam seus cultos de modo semelhante e é justamente neste ponto que entra a maior fonte de problemas para as religiões afro-brasileiras: os evangélicos adotam como dogma religioso o combate aos cultos afro-brasileiros, denominados pejorativamente de "macumba" e "macumbeiros", promovendo, inclusive, a divulgação de casos de "ex-pais-de-santo convertidos" e campanhas de evangelização de bairros inteiros, visando fechar terreiros de candomblé e umbanda, bem como buscando converter seus antigos praticantes aos dogmas evangélicos.

João do Rio nos ensina que a macumba "é uma religião, de caráter sincrético, oriunda da África, mas que adquiriu, no Brasil, uma certa significação ofensiva e desqualificadora com relação especialmente ao Candomblé e à Umbanda” (1976:56).

O mesmo autor ora citado ainda comenta: "os cultos de origens africanas no Rio de Janeiro chamavam-se, coletivamente, candomblés, como na Bahia, reconhecendo-se contudo, duas seções principais: os orixás dos cultos nagôs e os alufás dos cultos muçulmanos (malês) 
trazidos pelos escravos. Mais tarde, o termo genérico 'macumba' foi substituído pelo termo

'Kiumbanda'” (1976:56)

Os exemplos aqui são variados, mas há o caso de um pastor evangélico, Samuel Gonçalves, da Assembleia de Deus, que expressamente afirmou serem as religiões africanas "uma das três maldições do Brasil". E o neopentecostalismo, como diz estudioso da área, “leva ao pé da letra a ideia de que o diabo está entre nós, incitando seus seguidores divisá-lo nos transes rituais dos terreiros" (Jornal Folha de São Paulo, 30/7/2002).

Ricardo Mariano, em sua tese de doutorado (2001:75) afirma que muitas igrejas neopentescostais têm crescido "às custas das religiões afro-brasileiras, sendo que para uma de suas mais bem-sucedidas versões, a Igreja Universal do Reino de Deus, o ataque sem trégua ao candomblé e à umbanda e os seus deuses e entidades é um constitutivo de sua própria identidade".

Um aspecto específico merece atenção neste ponto. Antigamente, quando prevalecente a dogmática católica, o diabo era uma figura que personificava um mal inidentificável, impessoal, sem local ou momento determinado, mas, ao mesmo tempo, presente em todas as ações malignas do homem. Poderia estar, literalmente, em qualquer lugar, em qualquer homem, em qualquer ação que não fosse inspirada pelos ideais cristãos.

Os evangélicos, nesta nova configuração, retiram o diabo dessa situação de nãoidentificação para localizá-lo objetivamente nas religiões africanas. Passam a construir um dogma claro neste sentido: ali está o mal e como o bom fiel deve prestigiar o bem e combater o mal, torna-se conclusão natural e lógica que o "bom" evangélico combata, como e quando puder, as manifestações oriundas dos cultos africanos ou de origem africana, eis que estas são manifestações diabólicas, "do mal”.

Há ainda um terceiro ponto a ser levado em conta neste quadro fático. Ocorre que o evangelismo está crescendo fundamentalmente às custas do catolicismo. A "clientela" de ambos os segmentos é muito similar, e levando-se em conta que a base é cristã para as duas vertentes, os católicos que se tornam evangélicos não se sentem cometendo nenhum deslize ou falta grave, mas apenas ajustam sua fé de um modo mais atraente ou confortável para si mesmos.

Assim, o catolicismo já está suficientemente envolvido com seus problemas relacionados à perda de seus fiéis, à contestação de seus dogmas e até denúncias recorrentes de graves desvios de conduta por parte de seus lideres e dirigentes. Não há como imaginar que a maioria católica possa se ocupar em defender as religiões afro-brasileiras num contexto assim, muito embora, mesmo no passado, tais religiões sempre tenham sido vistas com reservas pelos católicos. 
Quando reunimos sob uma só análise os três aspectos acima, vemos que as religiões afro estão sob forte pressão no Brasil contemporâneo e estamos nos referindo à sua própria existência. Hoje a questão já não parece mais ser a aceitação social e cultural de adeptos do candomblé ou da umbanda, mas a coexistência com outras religiões, especialmente as diversas igrejas evangélicas.

\section{PROBLEMÁTICA DA [IN]TOLERÂNCIA RELIGIOSA ATUAL}

Claro que o quadro visto no tópico anterior nos leva a refletir sobre a tolerância aplicada à religião que, foi, ao menos na idade moderna, o nascedouro da concepção de tolerância hoje utilizada em diversos campos, mas de modo especial no trato da inclusão social e do direito das minorias.

Uma questão que nos parece candente é saber até que ponto esse embate evangélicos versus religiões afro-brasileiras é algo, em sua essência, característico e típico do Brasil, ou se estamos aqui assistindo apenas a uma das possíveis manifestações de uma intolerância generalizada presente na humanidade contemporânea e que aqui, no Brasil, encontrou na religião somente um campo fértil.

Veja-se o exemplo dos conflitos observados na Bósnia e região dos balcãs, de 1992 a 1996, com forte componente religioso, incluindo até mesmo a famigerada faxina étnica, consistente em estupros sistemáticos praticados pelo exercito sérvio, de maioria cristã ortodoxa, contra mulheres bósnias, de maioria muçulmana. O objetivo era étnico, mas a motivação era religiosa. O elemento muçulmano "manchava" ou maculava a sociedade que se buscava "limpar".

Lembremos ainda do tradicional conflito entre árabes e judeus, de notória origem religiosa, mas também étnica, cultural e histórica, de há muito com ares de manifestação eterna e sem horizonte de mudança. Os recentes episódios ocorridos na França chocam pela tradição de tolerância daquele país, muito embora a condição de atrito permanente entre muçulmanos - em sua grande maioria não-franceses ou imigrantes - e os franceses, que querem preservar a laicidade de seu estado, é algo inegável.

Aliás, sobre este último ponto, acima destacado, veja-se que a lei francesa que proibia a exibição de símbolos religiosos nas escolas daquele país, de março de 2004, foi recentemente confirmada. Mas já na primeira ocasião, ainda em 2004, a ONU pronunciou-se a respeito, externando sua apreensão com a lei francesa, por meio de sua relatora para assuntos religiosos, Asma Jahangir²: 
La ley francesa que prohíbe exhibir símbolos religiosos en las escuelas públicas tiene implicaciones indirectas negativas (...) su implementación por las instituciones escolares ya ha producido una serie de abusos que han provocado la humillación de las niñas musulmanas. Esa humillación sólo puede conducir a la radicalización de las personas afectadas.

Os recentes acontecimentos em Paris, com execução em massa de pessoas em locais de acesso público e por motivação religiosa, certamente é fato suficiente a fundar a observação de que religião segue sendo tema controverso e cuja dinâmica é ainda bastante desafiadora.

A tolerância, especialmente a tolerância religiosa, parece se revelar como um tema insolúvel quando observamos há quanto tempo se busca um convívio pacífico neste tema. Neste sentido, John Locke e Voltaire provavelmente foram os precursores no estudo do tema em tempos modernos. É bastante conhecida a Carta Acerca da Tolerância de Locke, em que referido autor afirma que "cada igreja é ortodoxa para consigo mesma e errônea e herege para as outras", indicando que já então se fazia sentir a dificuldade de convívio. Prossegue ainda o político e filósofo inglês (1978:9):

Seja no que for que certa igreja acredita, acredita ser verdadeiro, e o contrário disso condena como erro. De sorte que a controvérsia entre essas igrejas acerca da verdade de suas doutrinas e a pureza de seu culto é igual de ambos os lados; nem existe qualquer juiz, seja em Constantinopla, seja em qualquer outra parte do mundo, cuja sentença possa resolver a disputa

E arremata (1978:9):

\begin{abstract}
A decisão dessa questão cabe unicamente ao Juiz Supremo de todos os homens, a quem também cabe castigar os que erraram. Entrementes, avaliem esses homens como pecam odiosamente quando, acrescentando injustiça, se não ao seu erro, mas certamente ao seu orgulho, temerária e insolentemente atormentam os servos de outro mestre, que de modo algum estão obrigados a prestar-lhes contas ${ }^{3}$
\end{abstract} www.un.org/spanish/News/fullstorynews.asp?news $1 D=5488 \&$ criteria $1=$ Francia\&criteria2 $=$ niñas acesso em 26 de agosto de 2015.

${ }^{3}$ Trechos retirados de LOCKE, John. Carta acerca da tolerância. São Paulo: Abril Cultural, 1978, p. 9;

John Locke, contudo, trazia consigo aspectos dúbios e até mesmo paradoxais acerca da tolerância religiosa. Assim, o renomeado pensador inglês afirma, por exemplo, que "la tolerancia era la característica principal de la verdadera Iglesia (...) se ajusta al Evangelio de Jesucristo y la genuina razón de la humanidad" (1978:223), e, em seguida, defende que 
no deben ser tolerados de ninguna forma quienes niegan la existência de Dios. Los ateos no se sienten sujetos a las promesas, pactos y juramentos, que son los lazos de la sociedad humana". (1978:226).

No final, a tolerância funcionou na Europa muito mais por questões práticas, vale dizer econômicas, que por busca de entendimento e fraternidade entre os homens. $\mathrm{O}$ estabelecimento definitivo do capitalismo, com sua dinâmica própria, peculiar, naturalmente demandante de um ambiente estável, não necessariamente pacífico, mas estável e sem grandes contratempos, foi algo definitivo e bastante importante na sedimentação destas diversas religiões na sociedade, especialmente na Europa ${ }^{4}$.

Voltaire também se notabilizou ao relatar o caso Calas em seu "Tratado sobre a Tolerância". O ponto de partida é a morte de Marc-Antoine Calas, filho de Jean Calas, ambos integrantes de família protestante numa França majoritariamente católica. Além de perder o filho, Jean Calas é acusado de ter urdido sua morte, alegação baseada em boatos de que Jean assim procedera para evitar que seu filho se convertesse ao catolicismo.

Sumariamente, Jean Calas foi julgado e condenado à morte. Voltaire escreve, por vezes, num formato panfletário, exortando a tomada de medidas concretas a fim de que episódios como o Caso Calas não mais ocorressem. A tolerância é seu fio condutor (VOLTAIRE, 2000:29):

Temos judeus em Bordéus, em Metz, na Alsácia; temos luteranos, molinistas, jansenistas - não podemos tolerar e admitir calvinistas mais ou

\footnotetext{
${ }^{4}$ Lord Acton, no sentido aqui exposto, dizia que "el protestantismo estableció la intolerância como precepto imperativo y como parte de su doctrina, pero se vio obligado a admitir la tolerancia por las exigências de su situación, después de que los rigurosos castigos que impuso no hubieran conseguido detener el proceso de disolución interna". Na mesma linha, Sir William Petty dizia que "para el progreso del comercio, si es que este es un motivo suficiente, debemos ser tolerantes en cuestiones de opinión", no que é secundado por Hemry Kamen que, em dois trechos sintetiza as razões de comércio como forte elemento de pacificação no convívio religioso entre as várias crenças : "la expansión del capitalismo comercial, sobre todo en las dos principales potencias marítimas de Europa, Holanda y Inglaterra, fue un factor decisivo para acabar con las restricciones religiosas. El comercio solía ser un argumento de más peso que la religión. En el siglo XVI, la católica Venecia fue reacia a cerrar sus puertos a los barcos de los comerciantes luteranos de la liga hanseática"; "los viajeros protestantes creían que la pobreza de Espana e Itália era consecuencia directa de su catolicismo intolerante, y que la creciente prosperidad de Inglaterra provenía de su actitud liberal hacia los disidentes, en especial desde 1689. La revocación del edicto de Nantes vino a reforzar esta opinión", todos os trechos aqui citados foram retirados de KAMEN, op. cit., pp. 215 a 218.
}

menos nas mesmas condições que os católicos são tolerados em Londres? Quanto mais seitas houver, tanto menos perigosa cada uma será; a multiplicidade as enfraquece; todas são reprimidas por justas leis que proíbem as assembléias tumultuosas, as injúrias, as sedições e que estão sempre em vigor pela força coativa

O pensador ainda alinhava (VOLTAIRE, 2000:29): 
A Alemanha seria um deserto coberto pelas ossadas de católicos, evangélicos, reformados, anabatistas mortos uns pelos outros, se a paz de Westphalia não tivesse proporcionado enfim a liberdade de consciência

Assim, longe de ser inédita, a intolerância hoje observada no Brasil, envolvendo evangélicos e adeptos de religiões afro parece ser apenas mais um capítulo numa trajetória humana que, com maior ou menor intensidade, sempre assistiu a manifestações de intolerância religiosa.

Talvez o elemento real a ser analisado e levado em conta no trato do tema objeto desse estudo não seja exatamente a religião, mas o poder. Parece que o mote permanece: o homem quer o poder, busca o poder e, uma vez tendo-o para si, trata de dominar outros homens ou ao menos de impor seus valores.

\section{CONCLUSÃO}

A tolerância, e estamos ciente da obviedade de nossa afirmação, sempre parte de seu igual e contrário, a intolerância. Deveras, só pode se ver na contingência de tolerar algo quem, num primeiro momento, não tolerou aquela mesma manifestação ou objeto, considerando este último termo num sentido filosófico.

A tolerância assim, e há praticamente unanimidade nesta observação, é algo nobre e necessário, contudo, é ela própria fruto da não aceitação, constituindo-se um desafio da sociedade adotante da tolerância introjetá-la na vivência social de modo consciente, caso contrário sempre será necessário um esforço em sentido oposto, ou seja, no de combater a intolerância, criando focos de desgaste muitas vezes constantes. Martinez de Pisón bem indica o que queremos dizer (2001:59):

El acto de tolerancia presupone, por tanto, primeramente la existencia de razones para no admitir una acción, una ideologia o una creencia. Sin embargo, trás sopesar o ponderar outro tipo de razones éstas se sobreponen a las primeras de forma que se convierten en un motivo válido para cambiar la actitud y, en definitiva, permitir, tolerar dicha acción, ideología y creencia. Con razon se ha señalado que, vistas así las cosas, etimologicamente, 'tolerar' tiene um sentido negativo, implica una valorización negativa

O tipo de ponderação acima transcrita se mostra útil ao debate para fornecer um certo senso de profundidade à discussão, evitando, assim, basearmos nossas visões em platitudes estéreis cuja aceitação se aguarda seja concretizada como se fosse o curso de um rio que desagua no mar. A religião é hoje um foco extremamente importante de conflito numa abordagem mundial. Está no centro ou pelo menos na seqüência de fatos e atos que levam aos conflitos mais conhecidos. 
Tanto mais paradoxal é se observar tal aspecto quando se verifica que as religiões, de um modo ou outro, de uma forma ou outra, buscam uma conexão com o sagrado, um "religare", uma abstração em face do mundano e cujo objetivo central é imantar-se numa vibração sutil, elevada, celeste.

Todas as religiões, sem exceção, defendem valores comuns como a paz, o entendimento, a fé e a caridade ou ajuda ao próximo. No entanto, envolvem-se constantemente em conflitos em que elementos bem distantes desse ideário puramente religioso, como poder, dominação, ideologia e prevalência tomam espaço e marcam a forma dos relacionamentos que, assim, serão bem diversos de algo tão-somente ligado à busca do sagrado.

De todo modo, estamos conscientes que a exposição da questão aqui tratada pode nos levar a conclusões pessimistas e, de fato, o ambiente não é nada promissor. Contudo, das mais fortes crises podem nascer novas e mais avançadas concepções.

Em passagem pelo país, o Papa Francisco, talvez o líder religioso mais conhecido do mundo, mostrou que novos caminhos são possíveis, se abrindo para rever certos dogmas católicos, ao mesmo tempo em que exibiu disposição para dar um basta nos abusos e desmandos - alguns da própria cúpula da Igreja Católica - e voltar a instituição para os valores que inspiraram sua criação e que certamente nada tem a ver com escândalos financeiros, pedofilia e distanciamento dos fiéis.

Por outro lado, entre os evangélicos não se pode falar em discurso único. Certamente encontrar vozes de tolerância entre tal grupo parece ser tarefa realmente hercúlea, mas estão lá de algum modo. E podem se multiplicar. Se a tese acima defendida pela busca do poder estiver certa, podemos até interpretar recentes embates entre lideres de igrejas evangélicas como sinal de tal aspecto, e algo que pode, em algum momento, possibilitar uma mudança estrutural.

Quanto aos adeptos das religiões afro-brasileiras, especialmente Candomblé e Umbanda, nada mais pode ser sugerido a não ser resistir e prosseguir divulgando os valores mais relevantes de tais religiões, mostrando que uma cultura de paz, de amizade, de tolerância e de aceitação é plenamente possível sob o pálio de seus princípios constitutivos.

\section{REFERÊNCIAS}

ALEXY, Robert. Teoria de los Derechos Fundamentales. Madrid: Centro de Estudios Políticos y Constitucionales, 1997.

ALMEIDA, Ronaldo Romulo de. A universalização do Reino de Deus. Dissertação de 
mestrado em Sociologia. Campinas: Unicamp, 1995.

BARROS, Alberto Ribeiro. Direito e poder em Jean Bodin: o conceito de soberania na formação do estado moderno. São Paulo: EDUSP, 1999.

BOBBIO, Norberto. A era dos direitos. São Paulo: Campus, 1987.

CONTRERAS MAZARIO, José Maria. Las Naciones Unidas y la Protección de las Minorias Religiosas, Valencia: Tirant lo Blanch, 2004.

GAARDER, Jostein; HELLERN, Victor; NOTAKER, Henry. O livro das religiões. São Paulo: Companhia das Letras, 2002.

GIERKE, Otto von. Teorias Políticas de la Edad Media. Madrid: Centro de Estúdios Constitucionales, 1995.

GRANET, Marcel. A civilização chinesa. Rio de Janeiro: Otto Pierre, 1979.

KAMEN, Henry Arthur Francis. Nacimiento y desarrollo de la tolerancia en la Europa Moderna. Madrid: Alianza Editorial, 1991.

LOC KE, John. Carta acerca da tolerância. São Paulo: Abril Cultural, 1978.

LOUTH, Patrick. A civilização dos germanos e dos vikings. Rio de Janeiro: Otto Pierre, 1979.

MACHADO, Jonatas Eduardo Mendes. O regime concordatário entre a "libertas ecclesiae" e a liberdade religiosa. Coimbra: Coimbra, 1993,

MARIANO, Ricardo. Análise sociológica do crescimento pentecostal no Brasil. São Paulo: EDUSP, 2001.

MARTINEZ DE PISÓN, José. Tolerância y derechos fundamentales en las sociedades multiculturales. Madrid: Tecnos, 2001. 
MINHOTO, Antonio Celso Baeta. O federalismo brasileiro e a questão das competências constitucionais relativas à acessibilidade e inclusão social do portador de deficiência. São Paulo: Revista do Instituto dos Advogados de São Paulo, 2008.

MIRANDA, Jorge. Manual de direito constitucional. Tomo IV. Coimbra: Coimbra, 2000.

OTTO, Rudolf. O Sagrado: um estudo do elemento não-racional na idéia do divino e a sua relação com o racional. (tradução: Prócoro Velasquez Filho). São Bernardo do Campo: Imprensa Metodista, 1985.

PRANDI, Reginaldo. As religiões afro-brasileiras e seus seguidores. Revista Civitas, v. 3, $n^{\circ}$ 1, Jun-2003, Porto Alegre.

RIO, João do (Paulo Barreto). As Religiões no Rio. Rio de Janeiro: Nova Aguilar, Coleção Biblioteca Manancial nº 47, 1976.

SCHLEIERMACHER, Friedrich. Sobre a Religião. São Paulo: Fonte Editorial, 2000.

SODRÉ, Muniz. Por um conceito de Minoria. in "Comunicação e Cultura das Minorias", Raquel Paiva e Alexandre Barbalho (orgs.), São Paulo: Paulus, 2005.

TAYLOR, Charles. A política do reconhecimento. in "Multiculturalismo", K. Anthony Appiah (org), Lisboa: Instituto Piaget, 1998.

VOLTAIRE. Tratado sobre a tolerância. São Paulo: Martins Fontes, 2000.

WITTGENSTEIN. Ludwig. Tractatus logico-philosophicus. São Paulo: EDUSP, 2001. 